\title{
THE URGENCY OF HARMO-NIZATION OF OFFENSE TYPES IN THE QANUN JINAYAT AS AN EFFORT TO AVOID DUALISM IN APPLICATION OF LAW
}

\author{
Krisna Liza Agnesta, Doctoral Candidate \\ Nurjaya I Nyoman, Djatmika Prija, Aprilianda Nurini, Lecturers \\ Faculty of Law, University of Brawijaya, Malang, Indonesia \\ ${ }^{*}$ E-mail: agnes krisna@unsam.ac.id
}

\begin{abstract}
Aceh has privileges and special autonomy in running a government based on Islamic law. Based on this authority, Aceh has given birth to the Qanun Jinayat, namely provisions that regulate prohibited actions according to shari'a. Based on the Law on Governing Aceh, the Qanun Jinayat has a special position that cannot be fully equated with regional regulations' principles. During the implementation of the Qanun Jinayat, there has been a polemic of legal dualism with the national criminal law. As part of Indonesia, the Qanun Jinayat should harmonize its material content with the national criminal law. The urgency of harmonizing the two regulations is the focus of this article. This research is normative legal research but departs from the implications of the dualism that has occurred. This research shows that there is the neglect of horizontal harmonization in the formulation of the Qanun Jinayat, that systemic steps must be taken to prevent dualism of law in the formulation of the forthcoming Qanun Jinayat by avoiding the sectoral ego of the Aceh government by guiding the concept of "Limited Normality Principles".
\end{abstract}

\section{KEY WORDS}

Harmonization, offense, Qanun jinayat, dualism.

Aceh is one of the provinces in Indonesia with special privileges and autonomy, in the form of implementing Islamic law as a special character and spirit of life for the Acehnese people. This is under the statement in letter (c) the Considering Prevention of Law Number 11 of 2006 concerning Aceh Governance; "That the resilience and high fighting power comes from a view of life-based on Islamic shari'a which gave birth to a strong Islamic culture so that Aceh becomes a capital area for the struggle to seize and defend the independence of the Unitary State of the Republic of Indonesia".

In the preamble statement, it appears specifically that the central government recognizes that the Acehnese people struggle against Dutch military aggression so that most Acehnese who understands history have the view that the privilege of implementing Islamic law in Aceh is not just a gift from the central government but the Acehnese people regains its rights (Zamzami, 1990).

Juridically, the legality of the privilege and special autonomy for the province of Aceh is based on Law Number 44 of 1999 concerning the Implementation of the Privileges of the Special Region of Aceh, Law Number 18 of 2001 concerning Special Autonomy for the Province of the Special Region of Aceh as the Province of Nanggroe Aceh Darussalam and Law Number 11 of 2006 concerning Aceh Government (Krisna \& Prayitno, 2018).

Islamic shari'ah implemented in Aceh includes aqidah, sharia, and morals. The Islamic shari'ah includes worship, ahwal al-syakhshiyah (family law), muamalah (civil law), jinayah (criminal law), qadha (judiciary), tarbiyah (education), preaching, syiar, and defense of Islam. The matters above have been regulated in qanuns, and these qanuns can be tested materially by the Supreme Court (Hikmawati, 2008).

Law Number 11 of 2006 concerning Aceh Governance (after this referred to as the Aceh Government Law) has an exciting feature: the Aceh government is given authority regarding criminal law enforcement (jinayah) in implementing Islamic shari'ah-based governance. These aspects are detailed in the qanun as the implementation rules. Meanwhile, the authority to judge these jinayah cases rests with the Syar'iyah Court. 
As a judicial institution that implements Islamic courts, the Syar'iyah Court's authority is based on Islamic law in the national legal system. This authority is governed by qanuns and applies to the Muslim population of Aceh.

At present, Aceh already has a compilation of Islamic criminal law, namely Qunnun Number 6 of 2014 concerning the Law of Jinayat (after this called Qanun Jinayat) ratified on October 22, 2014 (Lubis \& Ritonga, 2016). Qanun Jinayat covers 10 (ten) chapters and 75 (seventy-five) articles. There are 10 (ten) speeches that are regulated in the Qanun Jinayat, among them:

- Jarimah Khamrr;

- Jarimah Māisir;

- Jarimah Khalwat;

- Jarimah Ikhtilat;

- Jarimah Zina;

- Jarimah Sexual Harassment;

- Jarimah Rape;

- Jarimah Qadzaf;

- Jarimah Liwath;

- Jarimah Musahaqah.

Various debates are currently developing regarding the types of fingers regulated in the qanun. There are types of fingers with the same elements of offenses that have been previously held in the national criminal law. This situation certainly creates confusion for law enforcers. It has the potential for dualism in applying the law to similar cases. The formulation of sanctions in the qanun differs from the national criminal law and different judicial competencies. It is quite interesting to examine the harmonization of the types of offenses in the Qanun Jinayat and offer solutions to avoid dualism in applying the law.

One of the arguments for this study's importance is that the application of Islamic shari'ah in Aceh is based on the people's ideological and religious views, namely Islam (Danial, 2015). That the Aceh custom is a custom that is thick with Islamic nuances and Islamic values that have been inherent in the heart since the long time of the Aceh kingdom before joining the Unitary Republic of Indonesia. Maybe some people will deny it because countries such as; Iran, Saudi Arabia, and other Islamic countries also apply Islamic criminal law as positive penalties. But this can be answered easily because the application of Islamic criminal law in Aceh covers a province, not a state. This makes Aceh different from other regions.

Articles or studies that examine the harmonization of the Qanun Jinayat and the national criminal law can be very rare. Tracing the study of privileges and special autonomy in Aceh in law enforcement, discussed more the Qanun Jinayat in national law, the existence of the Syar'iyah Court, and human rights concerning the punishment of caning in Aceh.

Meanwhile, the study to be carried out is certainly different from the writings that have been written before. This study will examine the urgency of harmonizing the types of offenses in the Qanun Jinayat to avoid dualism in applying the law. This study aims to understand the extent of the urgency of harmonizing the Qanun Jinayat with the national criminal law, analyzing the potential for dualism that occurs as a result of neglecting the harmonization phase of forming qanuns (regional regulations), as well as offering solutions in the formulation of the Qanun Jinayat so that it does not intersect with criminal law nationally while maintaining the kaffah enforcement of Islamic law in Aceh.

\section{RESULTS AND DISCUSSION}

The Position of the Qanun Jinayat in National Law. Aceh is one of Indonesia's provinces known as the 'Serambi Mekkah' area, a thick region with Islamic law and the only province in Indonesia that has implemented qanun. Qanun in Aceh has been known for a long time. One of the texts that became the reference was Tengku di Mulek's writing in 1257 entitled 'Qanun Syara' the Kingdom of Aceh' (Gayo, 2017). 
The word 'qanun' comes from the word 'cannonic', which means to command, excuse me. As it is widely used in the formal tradition, qanun's meaning extends to "standard rules accepted by an assembly". Arabic then turned it into "qanun ". During the Ottoman Caliphate, Sultan Sulaiman I was dubbed the lawgiver because of his achievements in restructuring the Ottoman legal system (Kamarusdiana, 2016).

The application of qanuns in Aceh can be divided into two types of qanuns, namely:

- Specific qanuns, namely qanuns formed in the framework of implementing Islamic syari'at. This is the result of an interpretation of Article 1 Paragraph 21 of Law Number 11 of 2006, which states that qanuns are laws and regulations similar to regional regulations;

- General qanuns, namely qanuns formed in the framework of running the wheels of Aceh governance, are the case with regional regulations in general. This results from the interpretation of Article 1 point 8 of Law Number 18 of 2001, which defines the Qanun of Nanggroe Aceh Darussalam Province as a Regional Regulation.

Referring to the qanuns' division in Aceh, the Qanun Jinayat is part of a particular type of qanun. This is because the Qanun Jinayat departs from the Acehnese people's philosophical view of life who believe that their existence on this earth cannot be separated from the rules (laws) established by Allah SWT. To enforce Islamic syari'at kaffah in Aceh, the Aceh government feels it is important to form the Qanun Jinayat, which normalizes the types of fingers prohibited in Islamic law and provides sanctions for those who break them.

Jufri Ghazib, quoting the Deputy Chairperson of the Great Chief, Taufiq, said that the position of the qanun is different when compared to the position of the different denominator. At first, qanun is a direct execution regulation from a call, while trading is not a direct execution regulation. Second, qanun is made specifically to regulate the implementation of Islamic shari'ah. They cannot be another qanun that regulates being expelled from Islamic law's executor (Manan, 2018).

Thus, the Qanun Jinayat has a specificity in its material content which correlates with its national law position. Qanun Jinayat cannot be confused with regional regulations in general. Therefore, from a hierarchical perspective, the law as lex specialis must be equated is Law Number 11 of 2006 with the applicable national laws. Therefore, if the qanun is substantially contrary to the national law, it can be justified juridically as long as the qanun regulated is the authority of the Aceh government in implementing Islamic law.

The Potential of Dualism in Application of Law in Aceh. The direction of legal development considers the plurality of society without limiting each citizen's rights. Still, it gives respect to every citizen to carry out living laws without neglecting other legal interests. In the context of a pluralistic Indonesian society, the law always lives and develops in line with the dynamics of society's development, both from a socio-cultural and political perspective (Coulson, 1991).

The authority of the Aceh Government to carry out religious life in implementing Islamic shari'ah is part of the direction of legal, political policy in Indonesia. It is constitutionally recognized that there is a plurality of indigenous peoples in every province in Indonesia. There are indigenous peoples with characteristics that have existed for hundreds of years. Qanun Jinayat is a positive law constructed from shari'ah (Ritter, 2005), figh (Ahmad, 1981), and 'urf.

Qanun Jinayat contains material Islamic syari'at. This is evidenced by the inclusion of Jarimah and' uqubat huddud in the qanun. Syahrizal Abbas explained that hudud in the Qanun Jinayat is a rule that is adopted as it is from the text and outlined in qanun (Abbas, 2015). Syahrizal placed the qanun in two dimensions: the divine dimension with the hudud rules and the human dimension with the ta'zir rules.

Thus the enactment of the Qanun Jinayat can be a reform of criminal law in Indonesia. Namely as a contribution to Islamic criminal law in the context of national law. Whereas Aceh is part of the Republic of Indonesia's Unitary State, the law is part of the national legal system. The following can be analyzed the elements of offenses contained in the Qanun Jinayat. 
Table 1 - The explanation of the criminal act (Krisna \& Prayitno, 2018)

\begin{tabular}{|c|c|c|c|}
\hline $\begin{array}{l}\text { Criminal } \\
\text { Acts }\end{array}$ & Details of Actions & The Criminal Code & $\begin{array}{l}\text { The Special Criminal } \\
\text { Law Outside the } \\
\text { Criminal Code }\end{array}$ \\
\hline Khamar & $\begin{array}{l}\text { Intoxicant and/or alcoholic beverages of } 2 \% \text { (two } \\
\text { percent) or more }\end{array}$ & $\begin{array}{l}\text { Article } 492 \text { and } \\
\text { Article } 536 \text { (having } \\
\text { an element of } \\
\text { criminal act different } \\
\text { from ganun) }\end{array}$ & - \\
\hline Maisir & $\begin{array}{l}\text { an act containing the element of betting and / or } \\
\text { an element of chance made between } 2 \text { (two) or } \\
\text { more parties,accompanied by an agreement that } \\
\text { the winning party will be paid a certain benefit } \\
\text { from the losers either directly or indirectly. }\end{array}$ & $\begin{array}{l}\text { Article } 303 \text { (having } \\
\text { an element of } \\
\text { criminal act different } \\
\text { from qanun) }\end{array}$ & - \\
\hline Khalwat & $\begin{array}{l}\text { The act of being in a closed or hidden place } \\
\text { between } 2 \text { (two) people of different sex, not } \\
\text { mahram, and without marital bond with the } \\
\text { willingness of both parties that lead to the act of } \\
\text { adultery }\end{array}$ & - & - \\
\hline Ikhtilat & $\begin{array}{l}\text { The act of making out like making out, touching, } \\
\text { hugging, and kissing between men and women } \\
\text { who are not husband and wife with the } \\
\text { willingness of both parties that lead to the act of } \\
\text { adultery }\end{array}$ & - & - \\
\hline \multirow[t]{2}{*}{ Zina } & Intercourse between a man & Article 284 & - \\
\hline & $\begin{array}{l}\text { or more with a woman or more without marital } \\
\text { ties with the willingness of both parties }\end{array}$ & $\begin{array}{l}\text { (having an element } \\
\text { of criminal act } \\
\text { different from } \\
\text { qanun) }\end{array}$ & $\begin{array}{l}\text { or more with a woman } \\
\text { or more without marital } \\
\text { ties with the } \\
\text { willingness of both } \\
\text { parties }\end{array}$ \\
\hline $\begin{array}{l}\text { Sexual } \\
\text { Abuse }\end{array}$ & By deliberately sexually abusing children & $\begin{array}{l}\text { Article } 287 \\
\text { (has been ruled out } \\
\text { by the Special Law } \\
\text { outside the Criminal } \\
\text { Code) }\end{array}$ & $\begin{array}{l}\text { Law Number } 35 \text { of } \\
2014 \text { on Amendment to } \\
\text { Law Number } 23 \text { of } \\
2002 \text { regarding Child } \\
\text { Protection }\end{array}$ \\
\hline Rape & Deliberate rape of both male and female children & $\begin{array}{l}\text { Article } 285 \\
\text { (has been ruled out } \\
\text { by the Special Law } \\
\text { outside the Criminal } \\
\text { Code) }\end{array}$ & $\begin{array}{l}\text { Law Number } 35 \text { of } \\
2014 \text { on Amendment to } \\
\text { Law Number } 23 \text { of } \\
2002 \text { regarding Child } \\
\text { Protection }\end{array}$ \\
\hline Qadzaf & $\begin{array}{l}\text { Accuses a person committing adultery without } \\
\text { being able to file at least } 4 \text { (four) witnesses }\end{array}$ & - & - \\
\hline Liwath & $\begin{array}{l}\text { The act of a man by placing his penis into the } \\
\text { other male anus with the willingness of both } \\
\text { parties }\end{array}$ & $\begin{array}{l}\text { Article } 292 \text { has an } \\
\text { element of the same } \\
\text { act }\end{array}$ & - \\
\hline Musahaqah & $\begin{array}{l}\text { The act of two or more women by mutually } \\
\text { rubbing limbs or faraj to obtain sexual } \\
\text { stimulation (pleasure) with the willingness of } \\
\text { both parties }\end{array}$ & $\begin{array}{l}\text { Article } 292 \text { has an } \\
\text { element of the same } \\
\text { act }\end{array}$ & - \\
\hline
\end{tabular}

Based on the table above, it can be explained that there are several criminal acts regulated in the qanun which have been alluded to in the Criminal Code but have different elements of action. For example, Jarimah khamar is the prohibition of alcoholic beverages. In the Criminal Code, the prohibition against alcohol emphasizes the element of disturbing public order, while in the qanun, everyone who drinks khamar, even though drinking liquor is not followed by acts of disturbing public order against the perpetrator, is still subject to criminal sanctions (Krisna \& Prayitno, 2018).

However, it turns out that the regulation of offenses for sexual abuse and rape of children has the same elements of the offense as the national criminal law, namely in Law Number 35 of 2014 concerning Amendments to Law Number 23 of 2002 concerning Child Protection and has been renewed. For the second time in Law Number 17 of 2016 concerning Second Amendment of Law Number 23 of 2002 concerning National Protection (Krisna \& Prayitno, 2018). 
Systemic Steps of Harmonization of Types of Offenses in Qanun Jinayat. Formation of statutory regulations is making statutory regulations starting from planning, preparation, drafting techniques, formulation, discussion, ratification, promulgation, and dissemination. Among the processes above, which are not explicitly stated but have an important role, namely the harmonization process.

The overlapping of laws and regulations, which are equivalent to the laws and regulations at the central and regional levels, is an issue that has always been raised on various occasions. This situation has led to dualism in the application of the law to similar cases. For example, the conflict of norms between the Law Qanun Law and the Child Protection Law shows that there has been dualism in the administration of convictions and the settlement of cases of acts of sexual violence against or in Aceh.

Table 2 - Two criminal cases of sexual harassment and rape in Aceh

\begin{tabular}{|l|l|l|}
\hline Year & District Court & Criminal Decision \\
\hline 2017 & No.28/Pid.B/2017/PN.Lgs & $\begin{array}{l}\text { imprisonment for 11 (eleven) years and a fine of Rp. 1,000,000,000. (one } \\
\text { billion) provided that if the fine is not paid, it is replaced by imprisonment } \\
\text { for 3 (three) months }\end{array}$ \\
\hline 2018 & No. 347/Pid.Sus/2018/PN Sgi & $\begin{array}{l}\text { imprisonment for 6 (six) years and a fine of Rp. 600,000,000, - (six } \\
\text { hundred million rupiahs) provided that if the fine is not paid, it is replaced } \\
\text { by a 2 (two) month imprisonment. }\end{array}$ \\
\hline 2020 & No. 32/Pid.Sus/2020/PN.Lgs & $\begin{array}{l}\text { imprisonment for 10 (ten) years and a fine of Rp. 100,000,000, - (one } \\
\text { hundred million rupiahs) provided that if the fine is not paid, it is replaced } \\
\text { by imprisonment of 6 (six) months }\end{array}$ \\
\hline 2017 & No. 02/JN/2017/MS.Lgs & $\begin{array}{l}\text { hundred million rupiahs) provided that if the fine is not paid, it is replaced } \\
\text { by imprisonment of 6 (six) months } \\
\text { deducted }\end{array}$ \\
\hline 2018 & No. 16/JN/2018/MS.Jth & $\begin{array}{l}\text { u'qubat Prison for 45 (forty-five) months is deducted from the period of } \\
\text { detention }\end{array}$ \\
\hline 2019 & No. 6/JN/2019/MS.Mbo & $\begin{array}{l}\text { u'qubat was whipped 30 (thirty) times the period of imprisonment was } \\
\text { deducted }\end{array}$ \\
\hline 2020 & No. 18/JN/2020/MS.Tkn & $\begin{array}{l}\text { u'qubat Prison for } 60 \text { (sixty-five) months is deducted from the period of } \\
\text { detention }\end{array}$ \\
\hline
\end{tabular}

Source: Results of field research and searches on the District courts' official websites and the Syar'iyah Court.

The above shows that the penal approach for acting of sexual violence against children in Aceh uses two legal rules, namely: Qanun Jinayat and the Child Protection Act. This means that the performer acts a speech as if there is a difference in the speech's thought, either a prison or a prisoner. The disparities of punishment that occur not only in the lightest number of events, but also in the type or form of speech to my students.

All state administrators are very aware of this but follow up to anticipate the problem never to resolve it. One of the reasons is that sectoral egos or interests of regional governments are still needed to minimize imbalances in implementing the drafting of laws and regulations.

The urgency of harmonizing existing laws and regulations in Indonesia is becoming increasingly significant in increasingly complex situations and conditions, among others, with the implementation of regional autonomy and the effects of globalization. The most important factor emerging from steps to harmonize laws and regulations is creating legal certainty and legal guarantees for whoever is interested (Jefferson, 1992).

The philosophy of the formulation of offenses in the Qanun Jinayat is enforcing Islamic law in Aceh. The Aceh government feels the need to form new crimes that are not accommodated in the national criminal law. That is the type of offense that is considered despicable in Islamic law and can damage the Acehnese generation's morals as is the goal of sharia law which is called Maqāsid Syarîah (al-Kurdi, 1980).

The systemic steps in harmonizing the Qanun Jinayat seem to use what is meant by horizontal harmonization. Horizontal harmonization departs from the lex posterior derogate legi priori principle, which means that a new statutory regulation overrides the old laws. The 
lex specialist derogate legi generalis principle a specific statutory regulation overriding statutory regulations of a specific nature general.

Horizontal harmonization based on the lex posterior derogate legi priori principle of statutory regulation in the same hierarchy and equal and in practice is regulated in the closing provisions of statutory regulation. In the closing provisions of statutory regulation, the status of existing statutory regulations is stipulated whether it is declared to remain valid as long as it does not contradict or is declared null and void.

The Qanun Jinayat includes articles containing the principle of lex posterior derogate legi priori. Namely Article 72, which reads: "In the event that Jarimah acts as regulated in this qanun and is also regulated in the Criminal Code (KUHP) or criminal provisions outside the KUHP, what applies is Jarimah's rule in this Qanun"

Article 72 in the Qanun Jinayat is used by law enforcement officials in Aceh as the basis for selecting Qanun Jinayat as the norm in resolving cases of sexual violence in Aceh. However, it seems that not all law enforcers have the same view. This is proven because the case is still being resolved at 2 (two) different courts: the District Court and the Syar'iyah Court.

Meanwhile, the application of lex specialis derogate legi generalis in horizontal harmonization is needed to form a law with a special form and characteristics and is different (sui generalis) from other laws and regulations to achieve certain goals. Qanun Jinayat and the Child Protection Act are types of statutory regulations that are specific-referring to the opinion of Eddy O.S. Hiariej, who explained that the contradiction in these regulations would affect the enforcement of criminal law because the formal laws governed by each of these norms were different. Therefore, another principle is needed to resolve this juridical problem, namely the lex specialis systematic principle (Hiariej, 2016).

Lex specialis systematic is a derivative of lex specialis derogate legi generalis. There are also criteria for systematic specialization that are objects of general definitions arranged more fully within special provisions. Whereas logical specialty has detailed defining criteria of crime set within the bounds of a general definition. The Qanun Jinayat, which is a derivative of the Aceh Government Law, specifically regulates 10 (ten) types of fingers relating to the enforcement of Islamic syari'ah law, which are based on the alquran and hadiths. Meanwhile, the Child Protection Law is also a special law that contains all aspects related to children's rights.

Regarding the contradiction between the two special arrangements, using the systematic lex specialis principle, the right choice in solving cases of sexual violence against children is to use the Child Protection Law because it is regulated more fully and in more detail in the framework of special criminal provisions.

Based on the description above, consider that the Qanun Jinayat is different from regional regulations in general and the harmonization analysis uses the lex posterior derogate legi priori principle and the lex specialis derogate legi generalis principle. Not able to solve the problem of dualism that will occur today and in the future. There needs to be a certain concept for the formulation of the types of offenses in the Qanun Jinayat, namely "Limited Normality Principles". Namely, the principle imposes certain limitations on the Qanun Jinayat in determining the type of offense to be normalized. It is seen from the political dimension of criminal law that the Qanun Jinayat only determines certain criminal arrangements to implement Islamic shari'ah. Therefore, the meaning of "certain" is meant among others:

- Despicable acts in accordance with Shari'ah, fiqh and 'urf, formulated through ljtihad Ulama;

- The act does not have the same meaning/element as what has been regulated in the national criminal law through harmonizing legislation.

Legal harmonization systemic thinking is needed to formulate norms as a basic conceptual framework for harmonizing the legal system. Without harmonizing laws and regulations currently being drafted, there will be legal uncertainty, disorder, and a sense of not being protected by the community. In this perspective, legal certainty will be perceived as a necessity that can only be realized through the harmonization of statutory regulations. 


\section{CONCLUSION}

The Aceh government is given the authority to enforce criminal law in implementing governance based on Islamic law. This dimension of authority has been implemented by establishing the Qanun Jinayat. Qanun Jinayat consists of 10 (ten) types of Jarimah, where these actions are prohibited according to Islamic law. There are 2 (two) types of fingers with the same elements as the national criminal law. This situation led to a polemic of dualism in the application of law in Aceh, which was tried in 2 (two) different courts, resulting in chaos in law enforcement and created legal uncertainty. The application of legal dualism results in disparity in punishment. Moreover, the Qanun Jinayat has principles that are not entirely the same as the national criminal law. The consideration of the severity of the sanctions and the types of sanctions formulated are different from the national criminal law.

The Qanun Jinayat, which cannot be considered the same as other regional regulations, is a strong consideration for the urgency of harmonizing national criminal regulations as a unit of the legal system in Indonesia. The use of the lex posterior derogate legi priori principle and the lex specialis derogate legi generalis principle is not sufficient to complete the potential for dualism that will occur in the future, it is necessary to develop the concept of "limited norming principle" in the steps to formulating the Qanun Jinayat, namely: (a) harmonization of policies formulation and (b) harmonization of material loads.

By harmonizing laws and regulations, a legal system will be formed to accommodate demands for legal certainty and justice. Likewise, in terms of law enforcement, harmonization of avoiding conflicts of norms for judicial bodies in Aceh, both the District Courts and the shari'ah courts. Regardless of the need for the establishment of Qanun Jinayat to achieve the implementation of Islamic shari'ah, it should be noted that the formation of the qanun remains within the unity of the national legal system present as a harmonious, relevant, and complementary provision of Islamic criminal law.

\section{REFERENCES}

1. Abbas, S. (2015). Maqashid al-Syariah dalam Qanun Jinayah di Aceh. Banda Aceh: Dinas Syari'at Islam.

2. Coulson, N.J. (1991). A History of Islamic Law. Edinburgh: Edinburgh University Press.

3. Danial. (2015). Fikih Mahzab Iran and Aceh (Analisis Konsep Pemidanaan dalam Hukum Pidana Iran and Aceh). Yogyakarta: Sekolah Pascasarjana UGM.

4. Gayo, A. (2017). Aspek Hukum Pelaksanaan Qanun Jinayat di Provinsi Aceh. Jurnal Penelitian Hukum De Jure, 17 (2).

5. Hiariej, E. (2016). Prinsip-Prinsip Hukum Pidana. Yogyakarta: Cahaya Atma Pustaka.

6. Hikmawati, P. (2008). Relevansi Pelaksanaan Syariat Islam di Provinsi Nanggroe Aceh Darussalam dengan Hukum Pidana Nasional. Kajian, 14 (2).

7. Jefferson, M. (1992). Criminal Law. London: Pitman Publishing.

8. Kamarusdiana. (2016). Qanun Jinayat Aceh dalam Perspektif Negara Hukum Indonesia. Jurnal Ahkam. 16 (2).

9. Krisna, L \& Prayitno, K. (2018). Dualism of Regulation of Criminal Law in Aceh: Criticizing the Neglected Legal Certainty. Proceedings of the $1^{\text {st }}$ Workhshop on Multidisciplinary and Its Application Part 1, WMA-01, 2008, 19-20 January 2018, Aceh, Indonesia.

10. Lubis, Z. \& Ritonga, H.B. (2016). Dasar-dasar Hukum Acara Jinayah. Jakarta: Prenamedia Group.

11. Manan, T. (2018). Mahkamah Syar'iyah Aceh dalam Politik Hukum Nasional. Jakarta: Prenadamedia Group

12. Ritter, R.M. (2005). New Oxford Dictionary for Writers and Editors. The Essential A-Z Guide to the Written Word, Oxford: Oxford University Press.

13. Zakariyah, A. (1981). Maqayis Al-Lugah. Bairut: Dar Al-Jail.

14. Zamzami, A. (1990). Jihad Akbar di Medan Area. Jakarta: Bulan Bintang.

15. Al-Kurdi, A. (1980). Al-Madkhal al-Fiqhi: al-Qawaid al-Kulliyah. Damsyik: Dar al-Ma'arif. 